\title{
Rapid impedancia- és küszöbfeszültség- emelkedés egy biventricularis ICD-sokk és bal kamrai elektródáján
}

\author{
Miklós Márton, Sághy László \\ SZTE ÁOK, II. sz. Belgyógyászati Klinika és Kardiológiai Központ, Szeged
}

Levelezési cím: miklosm91@gmail.com

\begin{abstract}
Bevezetés: Reszinkronizációs ingerlés kivitelezése során a bal kamrai elektróda implantációja gyakorlott operátorok esetén is kihívást jelenthet. Emiatt csak igazoltan sérült, a pacemaker beállításainak módosításával nem korrigálható esetekben kerül sor új bal kamrai elektróda implantációjának kísérletére.

Esetbemutatás: Biventricularis ICD-vel élö betegnél - akinél évekkel korábban pace/sense (p/s) elektródarész-sérülés miatt új p/s elektródaimplantáció is történt - rutinellenőrzés kapcsán végzett EKG-n a bal kamrai ingerlés hiánya volt észlelhető nagymértékű threshold-emelkedés miatt, egyidejű sokk, és bal kamrai elektródaimpedancia-emelkedés kíséretében. Röntgenátvilágítás során a sokkelektróda törése volt valószínűsíthető, a bal kamrai elektródán makroszkopikus sérülés nem látszott. A bal kamrai ingerlés konfigurálásával (LV tip to RV coil $\rightarrow$ LV tip to can) a bal kamrai impedancia és threshold normalizálható volt majd új sokkelektróda implantációjára került sor.

Megbeszélés: A sokkelektróda p/s részének tönkremenetelét követően 10 évvel a sokktekercs is meghibásodott, amely egyidejüleg az alkalmazott ingerlési konfiguráció miatt a bal kamrai ingerlés megszủnését is eredményezte. Az ingerlési vektor megváltoztatásával az LV-ingerlés helyreállítható volt, a megelőző helyzet megtévesztően keltette bal kamrai elektródasérülés gyanúját.

Kulcsszavak: CRT-D, elektródatörés, impedanciaemelkedés, konfigurációváltás, unipoláris elektróda
\end{abstract}

Rapid and simultaneous increasing of the impedance and the pacing threshold in the shock and CS electrode of a CRT-D device

Introduction: During the procedure of cardiac resynchronisation therapy, positioning of the CS electrode can be challenging. According to this observation, implantation of a new CS electrode should only be reserved for the completely fractured or broken leads.

Case: Left ventricular no capture has been detected during regular follow-up in a CRT-D device patient caused by significantly increased pacing threshold and impedance of the shock and left ventricular electrode simultaneously at the same time. The fluoroscopy showed shock lead damage at the level of the clavicle however the LV electrode seemed to be intact. Changing the pacing polarity from LV tip $\rightarrow$ RV coil to LV tip $\rightarrow$ Case led to normalization of the impedance and threshold values. During the follow-ups the patient became asymptomatic and the biventricular capture remained constant. Discussion: Ten years after the failure of the pace/sense part of the shock electrode, the high voltage part has been broken, which resulted in the absence of the left ventricular capture. Changing the configuration of the pacing vector excluding the right ventricular shock coil, the left ventricular capture could be restored. The previous situation showed the fracture of the left ventricular electrode falsely.

Keywords: CRT-D, electrode fracture, increased impedance, configuration, unipolar electrode

\section{Bevezetés}

A CRT-D-kezelés az egyik alappillére az alacsony ejekciós frakcióval járó, optimális gyógyszeres terápia ellenére is szimptomatikus szívelégtelenségnek, amenynyiben Bal Tawara-szár-blokk is jelen van megfelelően széles QRS-komplexus kíséretében (1). Mütéttechnikai szempontból a jobb kamrai, illetve jobb pitvari elektró- da pozícionálása az esetek döntő többségében egyszerüen kivitelezhető, azonban a bal kamrai elektróda CS-ágrendszerbe való elhelyezése gyakrabban jelent kihívást. Elektródadiszfunkció gyanú esetén ezért elsődleges szempont, hogy új elektróda implantációja mellett csak akkor döntsünk, ha programozással a felmerülö probléma nem orvosolható. 


\section{Esetismertetés}

58 éves, noniszkémiás DCM-mel és krónikus pitvarfibrillációval rendelkező férfi 2006-ban hemodinamikai instabilitással járó kamrai tachycardia, bal Tawaraszár-blokk és rossz balkamra-funkció miatt szekunder profilaktikus biventricularis ICD-implantáción esett át. Gyógyszeres terápia ellenére nem megfelelő biventricularis pace arány miatt még ebben az évben AV-csomó-abláció történt. 2009-ben az ICD által többször detektált, 200 ohm alá csökkenő jobb kamrai (RV) pace impedancia és oversensinget okozó elektromoszajesemények miatt osztályos obszerváció történt. Átvilágítás során makroszkópikus sérülést nem észleltünk, defibrillációs teszt sikeres volt. Ezt követően új pace/ sense elektródaimplantáció és telepcsere történt. Az utolsó generátor cserére 2016-ban került sor, majd a 2018 májusában történt ambuláns kontroll és rutin 12 elvezetéses EKG során pitvarfibrillációs alapritmus mellett jobb kamrai VVI pacemaker-ritmus volt látható bal kamrai no capture mellett (1. ábra).

Az interrogáció során detektáltuk, hogy a korábban stabil impedancia trend görbékben a sokkelektróda magas feszültségü (HV) és a bal kamrai elektróda pace impedanciája hirtelen, szimultán és jelentősen megemelkedett, a magas feszültségü elektróda impedanciája 150 ohm fölé került, míg a bal kamrai elektróda impedanciája 1707 ohm-ra nőtt (2. ábra). A jobb kamrai pace/sense elektróda impedanciája továbbra is stabil maradt. Saját ritmus a korábbi AV-csomó-abláció miatt nem volt észlelhető, a beteg pacemaker-dependens volt. A bal kamrai threshold a korábbi 1,2 voltról 3,2 voltra nőtt 0,4 msec-os pulzusszélesség mellett a korábban is alkalmazott standard konfigurációban (LV tip $\rightarrow$ RV coil), amely magasabb volt, mint a programozott pulzusamplitúdó (2 V@ 0,4 msec). Megemelt bal kamrai pulzusamplitúdóval a bal kamrai ingerlést ismételten sikerült elérni. A jobb kamrai threshold nem változott.

$A z$ átvilágítás során a sokkelektróda makroszkópikus sérülése látszott a proximális szakaszon, a clavicula alatt. A bal kamrai elektródán látható törés nem volt (3. ábra).

A nagymértékben és hirtelen megemelkedett HV-impedancia és az átvilágítás során detektált sérülés miatt új sokkelektróda implantációja nem látszott elkerülhetőnek, azonban új CS-elektróda implantációja a sokkelektróda mellett nagymértékben növelte volna a mütét nehézségét és időtartamát, és csökkentette volna a várható sikerarányt, így a mütétet megelőzően programozási megoldást próbáltunk keresni.

Unipoláris bal kamrai elektróda révén a Biotronik Itrevia 7 HF-T CRT-D generátor által felkínált lehetőségesek közül csak az eddiginek megfelelő „LV tip to RV coil”, vagy az úgynevezett valódi unipoláris (LV tip to Case) konfiguráció volt programozható (4. ábra). Valódi unipolárisba való programozást követően a bal kamrai elektróda impedanciája a korábbi 1707 ohm-ról 477 ohm-ra változott, míg a bal kamrai threshold $1 \mathrm{~V}$ alá csökkent 0,4 msec-os pulzus szélesség mellett. Ezzel a beállítással új CS-elektróda implantációja elkerül-

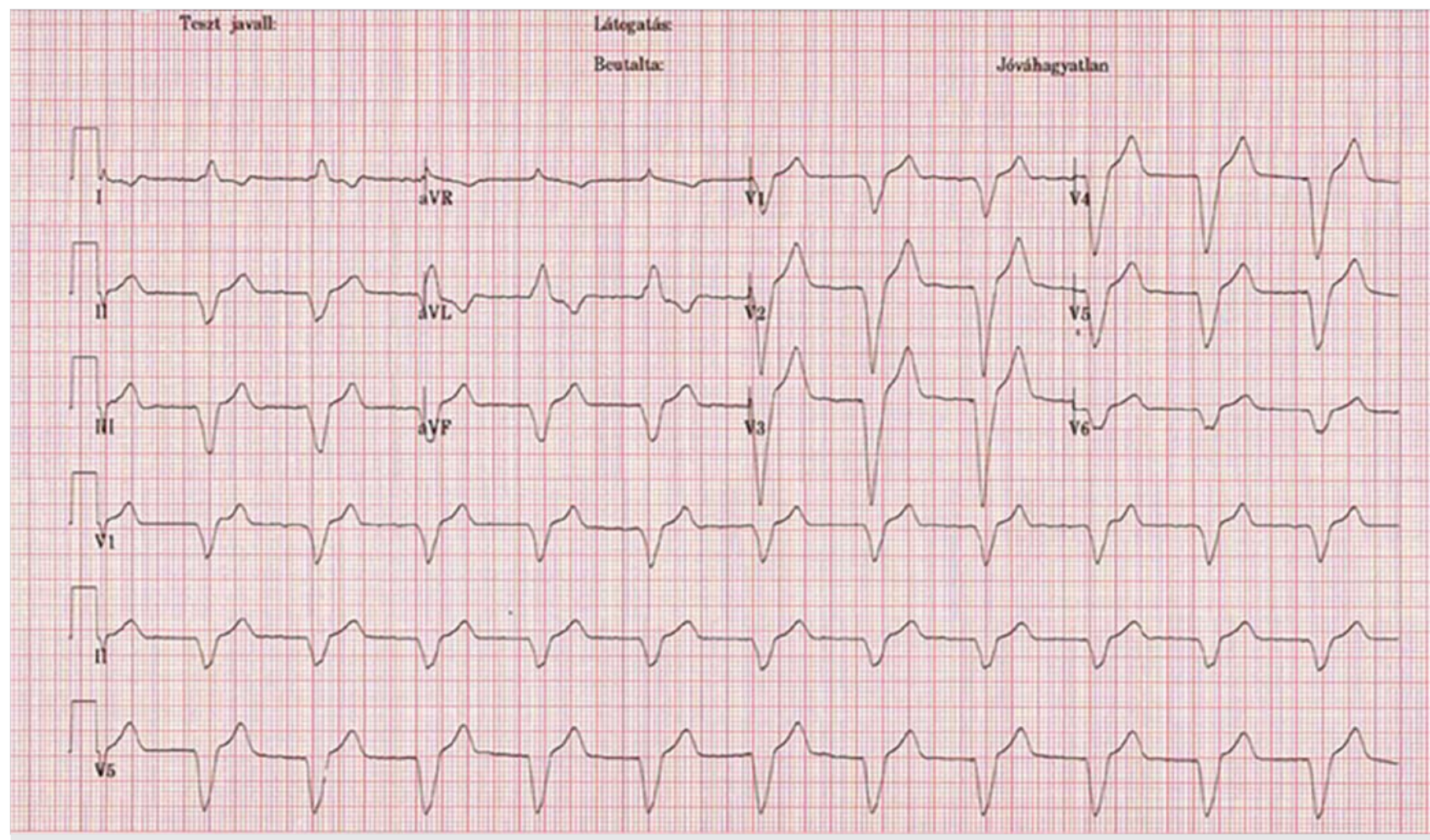

1. ÁBRA. A beállított VVI-BIV-mód ellenére az EKG-n jobb kamrai ingerlés képe látható 

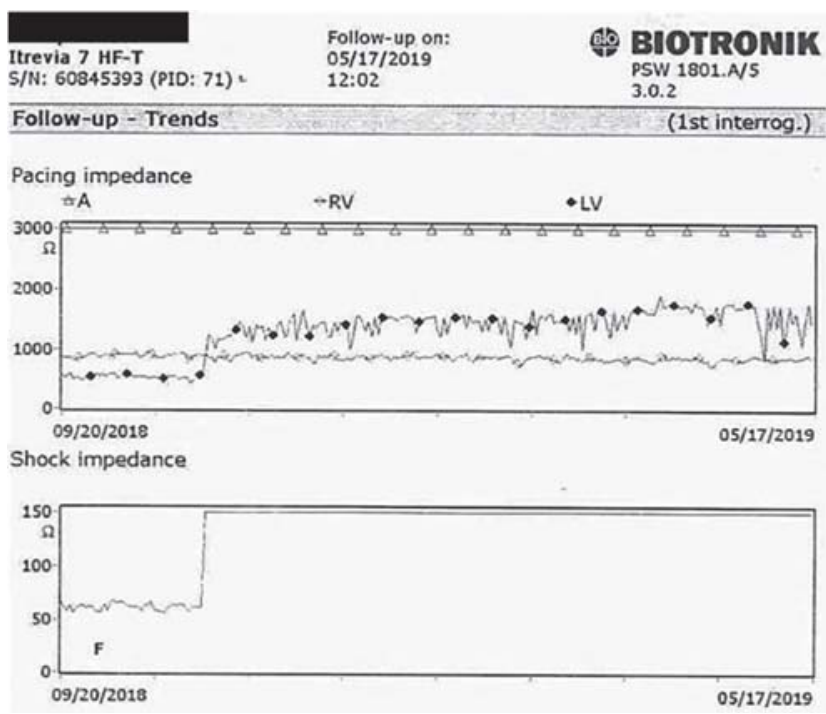

\section{2. ÁBRA. Szimultán impedanciaemelkedés a HV és a bal} kamrai elektródán

hetővé vált, az elvégzett műtét során a beteg új sokkelektródát kapott. A régi - 13 éves sokkelektróda és 10 éves pace/sense elektróda - extrakcióját a haszon-kockázat mérlegelését követően nem kíséreltük meg.

A posztoperatív EKG-n effektív biventricularis ingerlés látható (5. ábra), amely a féléves ICD-ellenőrzés során is igazolható volt, változatlanul jó ingerlési és impedanciaparaméterek mellett.

\section{Megbeszélés}

A 2006-os első implantációt követően 3 évvel a jobb kamrai elektróda meghibásodását észlelték, azonban

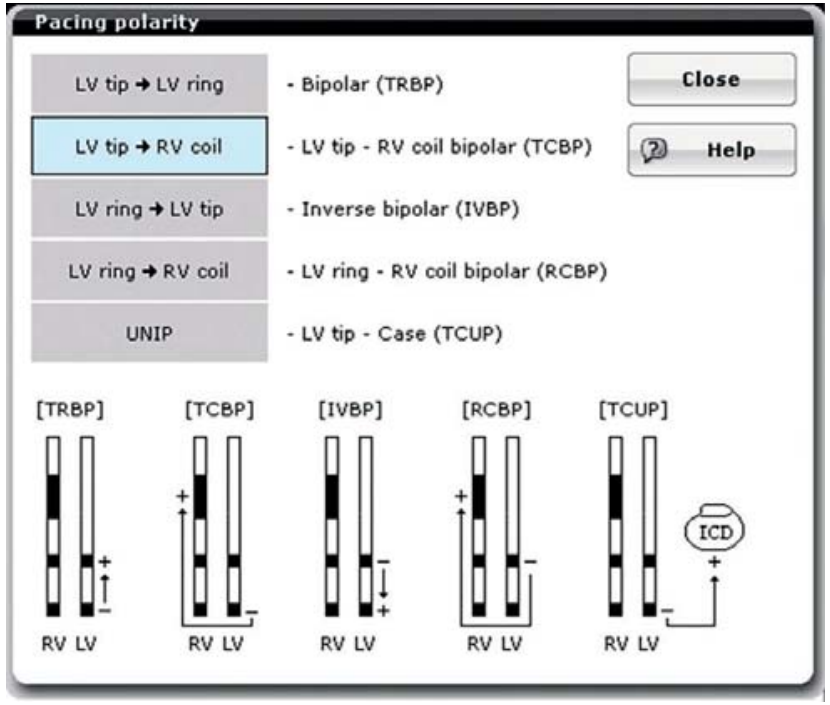

4. ÁBRA. Biotronik Itrevia 7 HF-T készüléken elérhető bal kamrai konfigurációs lehetőségek. Világoskék színnel jelölve az eredeti programozás

ekkor még a sokktekercs hibátlanul működött, a pace/ sense rész azonban károsodott. Ekkor is felmerült már a sokkelektróda komplett extrakciója, mivel 3 éves elektróda révén ez valószínűsíthetően relatív könnyü beavatkozás lett volna. Végül a p/s rész elektromos szigetelése és új pace/sense elektróda implantációja mellett döntöttek $(2,3)$.

10 évvel ezt követően ismételten elektródasérülés gyanúja miatt történt osztályos felvétel. Ezúttal az eredeti sokkelektróda HV komponensének impedancia emelkedése látszott, amely minden bizonnyal egy progresszív, dezintegráló Crush-szindróma következményeként alakult ki több mint egy évtizeddel a $\mathrm{p} / \mathrm{s}$ komponens meghibásodását követően. Az átvilágítás

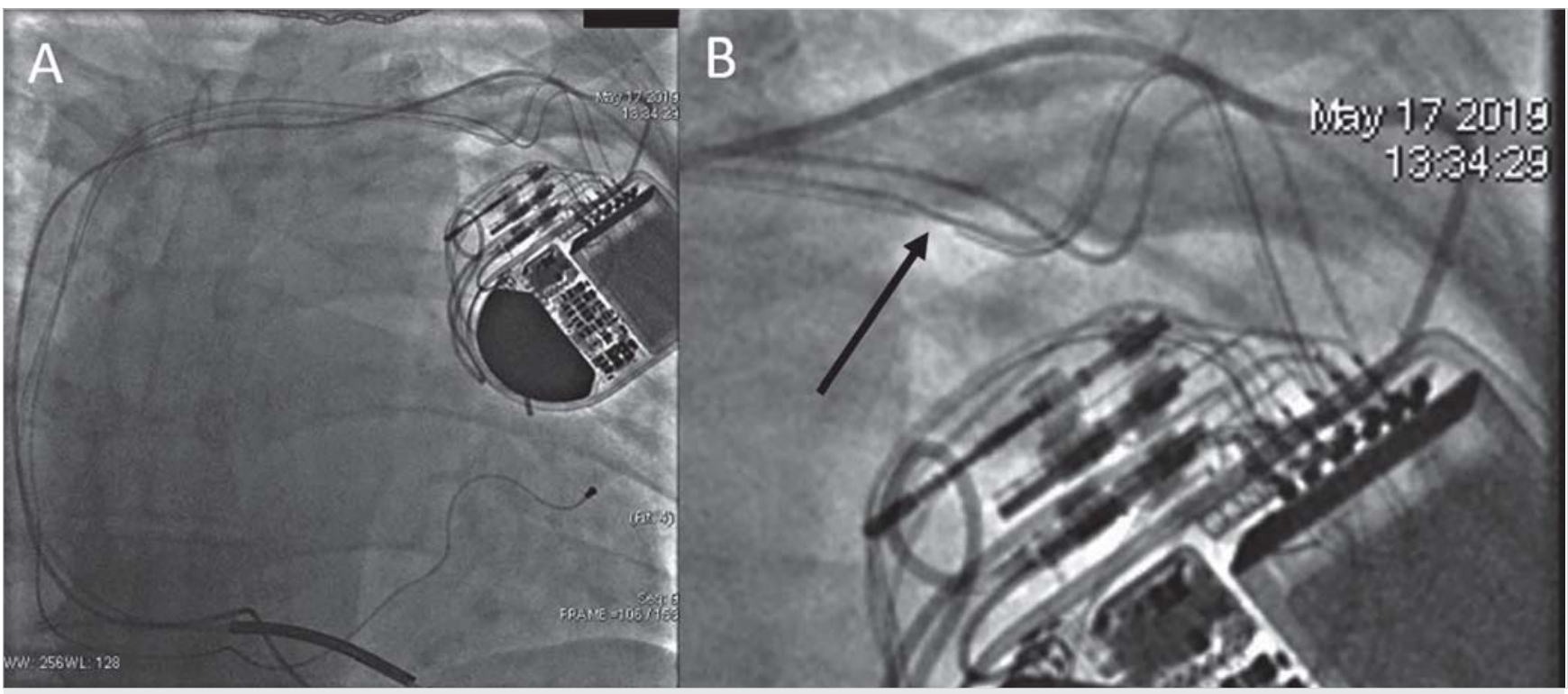

3. ÁBRA. Fluoroszkópia során észlelhető sokkelektródatörés. A-KÉP: AP-nézet. B-KÉP: az előző kép 2x-es nagyítása. A nyíl jelöli a törés helyét 


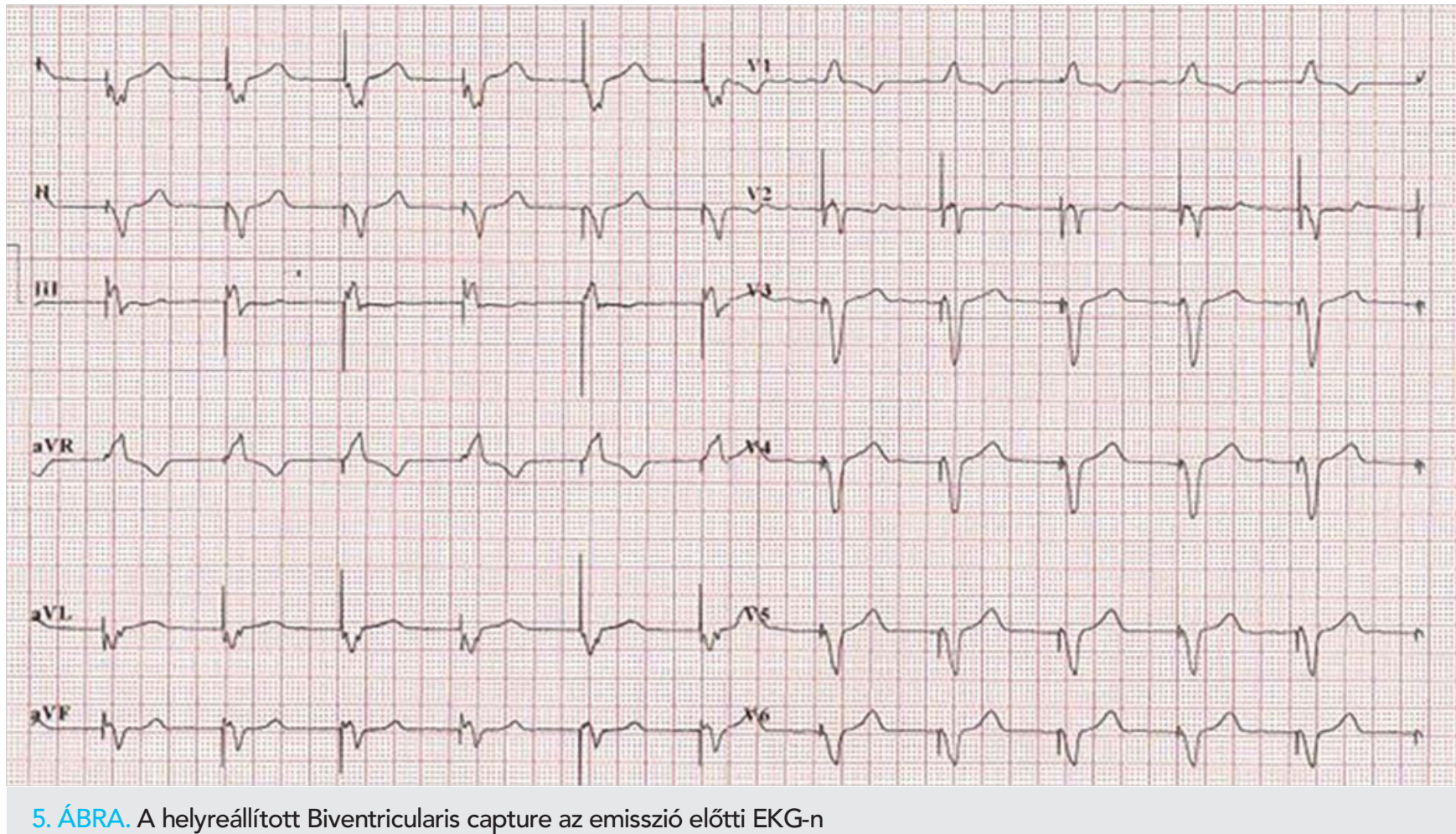

5. ÁBRA. A helyreállított Biventricularis capture az emisszió előtti EKG-n

során a sokkelektróda makroszkopikus sérülését is észleltük, amely a 2009-es átvilágítás alkalmával még nem látszott. A CS-elektróda intakt volt. Mivel az eredeti programozás „LV tip to RV coil” volt, így az áramkörben anódként a sokkelektróda is részt vett. Ilyen esetekben gondolni kell rá, hogy a szimultán észlelt, a HV és a bal kamrai elektródát is érintő impedanciaemelkedés valójában a sokkelektróda sérülésének következménye. Ennek megfelelően a konfigurációmódosítást követően (LV tip to Can) ismételten normál tartományba eső bal kamrai elektródaimpedanciát (477 ohm) és $1 \mathrm{~V}$ alá csökkent ingerlési küszöböt észleltünk 0,4 msec-os pulzusszélesség mellett. Így értelemszerüen új bal kamrai elektróda implantációja

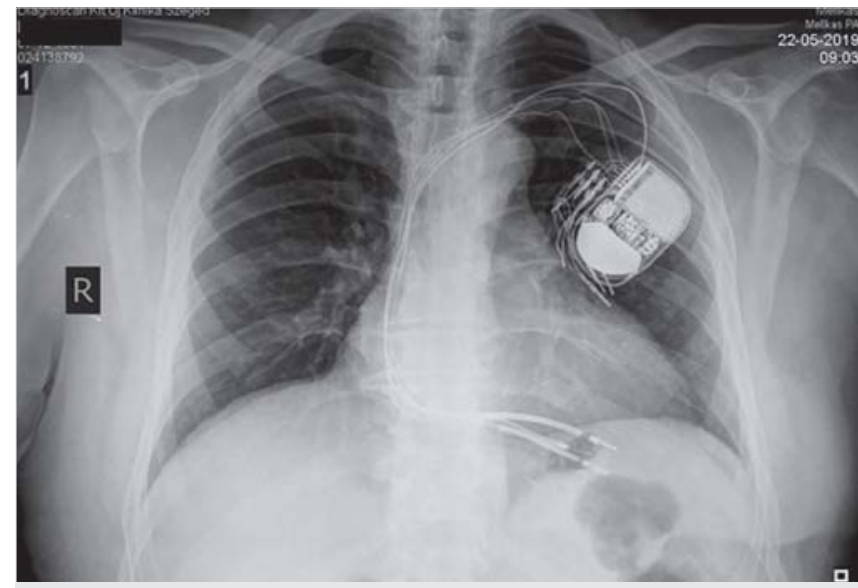

6. ÁBRA. Sokkelektróda-implantációt követő MRTG PA-nézet nem merült fel. Az új sokkelektróda beültetése szövődménymentesen megtörtént (6. ábra).

Féléves kontrollon hibátlan biventricularis capture-t és ICD-paramétereket észleltünk. A bal kamrai ingerlést a módosított (LV tip to Case) konfigurációban hagytuk, azonban az új sokkelektródával a differenciáldiagnosztikai lépések lezártával az eredeti beállítások is optimálisak lettek volna.

A fentiek alapján megállapítható, hogy amennyiben két elektródán egy időben jelentkezik impedanciaemelkedés, úgy ennek hátterében mindkét elektródát érintő törés valószínütlen, ezért egyéb okokat szükséges keresni.

\section{Irodalom}

1. Ponikowski P, Voors AA, Anker SD, et al. ESC Scientific Document Group. 2016 ESC Guidelines for the diagnosis and treatment of acute and chronic heart failure: The Task Force for the diagnosis and treatment of acute and chronic heart failure of the European Society of Cardiology (ESC) Developed with special contribution of the Heart Failure Association (HFA) of the ESC. European Heart Journal 2016 July 14; 37(27): 2129-2200. https://doi.org/10.1093/eurheartj/ ehw128

2. Nair Sandeep G, et al. Monitoring for and Diagnosis of Lead Dysfunction. Cardiac Electrophysiology Clinics 10(4): 573-599. https:// doi.org/10.1016/j.ccep.2018.07.004

3. Maria G. Bongiorni, Haran Burri, Jean C Deharo, Christoph Starck, Charles Kennergren, et al. ESC Scientific Document Group, 2018 EHRA expert consensus statement on lead extraction: recommendations on definitions, endpoints, research trial design, and data collection requirements for clinical scientific studies and registries: endorsed by APHRS/HRS/LAHRS. EP Europace 2018 July; 20 (7): 1217. https://doi.org/10.1093/europace/euy050 